\title{
Transformation of human embryonic stem cells by HTLV-1 Tax
}

\author{
Linda Zane, Junichiro Yasunaga, Takao Kinjo, Gustavo Brito de Melo, Kuan-Teh Jeang* \\ From 15th International Conference on Human Retroviruses: HTLV and Related Viruses \\ Leuven and Gembloux, Belgium. 5-8 June 2011
}

HTLV-1 encodes a viral oncoprotein Tax which has been shown to transform primary rodent cells. Tax can also immortalize human primary $\mathrm{T}$ lymphocytes. However, to date transformation by Tax of human cells has been unsuccessful $[1,2]$. Based on the cancer stem cells (CSCs) hypothesis that tumor growth is caused by the proliferation of only a small number of CSCs, we reasoned that ATL cells may arise from the infection by HTLV-1 of not mature CD4+ T cells (as currently thought) but by viral infection of more rare hematopoietic precursor cells. Thus, Tax may be able to transform early undifferentiated human cells, but not later differentiated cells. We asked whether Tax could transform human Embryonic Stem Cells (ESCs) vs. human skin fibroblast BJ cells. Undifferentiated ESCs were transfected with Tax, and these cells were injected into immunodeficient NOD-SCID/IL2 $\gamma$ R null (NOG) mice. We assessed tumor incidence after injection and found that Tax enhanced the tumorigenesis of ESCs $(p=0.012$, Gehan-Breslow-Wilcoxon test). By contrast, our transformation studies using Tax in differentiated human BJ cells have been consistently unsuccessful. Based on these results and others to be presented, we conclude that HTLV-1 Tax is more capable of inducing tumorigenesis of undifferentiated than differentiated human cells.

\section{Published: 6 June 2011}

\section{References}

1. Higuchi M, Fujii M: Distinct functions of HTLV-1 Tax1 from HTLV-2 Tax2 contribute to key roles in viral pathogenesis. Retrovirology 2009, 6:117.

2. Matsuoka M, Jeang KT: Human T-cell leukemia virus type 1 (HTLV-1) and leukemic transformation: viral infectivity, Tax, HBZ and therapy. Oncogene 2011, Epub a head of print.

\footnotetext{
* Correspondence: kj7e@nih.gov

National Institute of Allergy and Infectious Diseases, NIH, USA
}

doi:10.1186/1742-4690-8-S1-A164

Cite this article as: Zane et al:: Transformation of human embryonic stem cells by HTLV-1 Tax. Retrovirology 2011 8(Suppl 1):A164.

Submit your next manuscript to BioMed Central and take full advantage of:

- Convenient online submission

- Thorough peer review

- No space constraints or color figure charges

- Immediate publication on acceptance

- Inclusion in PubMed, CAS, Scopus and Google Scholar

- Research which is freely available for redistribution

Submit your manuscript at www.biomedcentral.com/submit

\section{Biomed Central}

